\author{
Nikolay Bulychev ${ }^{1,2}$, Edward Kisterev ${ }^{1}, Y u l i a$ Ioni $^{1}$, Klaus Dirnberger ${ }^{2}$, Vitali Zubov ${ }^{3}$ \\ and Claus Eisenbach ${ }^{2,4}$
}

\title{
N AN OSTRUCTURAL CHARACTERISTICS OF POLYMER ADSORPTION LAYERS FORMED UNDER ULTRASONIC TREATMENT ON METAL OXIDES SURFACE IN AQUEOUS DISPERSIONS
}

\author{
${ }^{1}$ N.S. Kurnakov Institute of General and Inorganic Chemistry of Russian Academy of Sciences, \\ 31 Leninsky Ave., 119991 M oscow, Russia \\ 2 Institute for Polymer Chemistry, University of Stuttgart, 55 Pfaffenwaldring, D-70569 Stuttgart, Germany \\ 3 Lomonosov M oscow State Academy of Fine Chemical Technology, \\ 86 Vernadskogo Ave., 117571 M oscow, Russia \\ ${ }^{4}$ Research Institute for Pigments and Coatings, 37Allmandring, D-70569 Stuttgart, Germany
}

Received: March 19, 2010 / Revised: M ay 14, 2010 / Accepted: December 15, 2010

() Bulychev N., Kisterev E., Ioni Yu., Dirnberger K., Zubov V., Eisenbach C., 2011

\begin{abstract}
The course and the result of the surface modification of titanium dioxide and ferrous oxide pigments in aqueous dispersion by ethylhydroxyethylcellulose (EHEC) without and with mechanical treatment of the dispersion by ultrasonic power was studied by the electrokinetic sonic amplitude (ESA) method. The evaluation of the ESA data showed that the ultrasonic treatment causes a significant thickness increase of the EHEC layer on the pigment which is primarily attributed to the ultrasonically induced activation of the pigment surface. The thickness of the polymer adsorption layer derived from ESA measurements was confirmed by TEM investigations. The ultrasonic treatment leads to significant changes of the adsorption layers properties and is a promising method for the surface modification of pigments with regard to dispersion stability.
\end{abstract}

Keywords: aqueous dispersions, polymers, electrokinetic sonic amplitude method, polymer adsorption layers, ultrasonic treatment.

\section{Introduction}

In recent years, aqueous colloidal dispersions of pigments have been of increasing interest from both scientific and practical points of view. They are important, ecologically friendly colloidal systems widely used in polygraphic and paint industries. The pigment particles are usually of 200-2000 $\mu \mathrm{m}$ diameter and they are strongly aggregated. In order to achieve a good stabilization in aqueous pigment dispersions, many formulations were proposed [1-8]. Earlier we reported about the role of mechanical, e.g. ultrasonic treatment for obtaining of highly stable dispersions [7, 9]. It was shown, that using of polymer surfactants in combination with mechanical action can significantly improve the quality of dispersed systems. However, specific aspects of the pigment-polymer interaction and structure formation of adsorption layers especially under mechanical, i.e. ultrasonic action have not yet been studied in detail.

Electrokinetic sonic amplitude (ESA) measurements have been demonstrated to be a powerful method that could provide the desired information about the process of polymer adsorption [7-9] and was employed in this work. Commercial ethylhydroxyethylcellulose (EHEC) was used as the stabilizer of $\mathrm{TiO}_{2}$ and $\mathrm{Fe}_{2} \mathrm{O}_{3}$ aqueous dispersions. The polymer layers created on the particle surfaces in the absence and presence of mechanical (ultrasonic) action were investigated.

\section{Experimental}

\subsection{M aterials}

As pigments, the titanium dioxide rutil pigment Kronos 2310 with the particle size of $0.3 \mu$, ferrous oxide Bayerfox with the particle size of $0.3 \mu$ were employed as received. EHEC with the molecular weight of 60.000 was provided by Berol.

\subsection{Techniques}

For preparation of aqueous pigment dispersions, the pigment was added to water or to the aqueous polymer 
solution and dispersing of the pigment was first achieved by means of a laboratory stirrer (700 rpm for $10 \mathrm{~min}$ ). When ultrasonification was applied, the system was subsequently treated with ultrasound for 2 min with an ultrasonic generator UZDN-2 or Branson Sonifier B-12 with the actual power of $1.5 \mathrm{~W} / \mathrm{cm}^{2}$.

The pigment-polymer interaction and the polymer adsorption layer formation were investigated by electrokinetic sonic amplitude (ESA) measurements as described elsewhere [12]. The particle size was measured by both ESA (cf. [12]) and by using Nanosizer (Malvern Instruments). The standard optical equipment was used for refractive index measurements. Transmission electron microscopy (TEM) investigations were carried out according to the standard procedure. The samples of the pigment dispersions were diluted with distilled water by the factor of 100, then dropped on the TEM grid of $3 \mathrm{~mm}$ diameter and dried in the air for 1 day. The TEM pictures were taken by using a Jeol 2000 FX device under the voltage of $200 \mathrm{kV}$.

\section{Results and Discussion}

Data reported in literature $[7,9,10]$, showed that mechanical, in particular, ultrasonic treatment of aqueous dispersions of pigments in the presence of polymeric stabilizers leads to a significant enhancement of the stability of these dispersions as compared to dispersions prepared without ultrasonic treatment. It was proven by IR-analysis that the thickness and stability of the polymer adsorption layers were increased and improved by ultrasonification [9]. The optimal parameters of the ultrasonic treatment and their influence on the properties of dispersed systems were established [11]. However, the effect of the ultrasonic treatment on the pigment-polymer interaction and polymer adsorption is still obscure and needs further investigation for better elucidation of the phenomena observed.

ESA measurements of aqueous dispersions of $\mathrm{TiO}_{2}$, stabilized by ethylhydroxyethylcellulose (EHEC), give quantitative information about the process of polymers adsorption as reflected first from the dependence of the dynamic mobility $\mu$ on the relative polymer concentration (cf. [12-14]) as shown in Figs. 1 and 2, and secondly from the comparison of this dependency for systems without and with ultrasonic treatment (Fig. 2).

As one can see from the comparison of Figs. 1 and 2, ultrasonic treatment has a distinct effect on the behavior of the pigment-polymer suspension. Without ultrasonic action, the formation of a polymeric adsorption layer on the pigment surface seems to be reached at $1 \mathrm{wt} \%$ EHEC in relation to the pigment concentration (saturation concentration as indicated by the unchanged dynamic mobility with the further increase of polymer concentration) followed by polymolecular adsorption between about 2 and $3 \mathrm{wt} \%$. In the presence of ultrasonic action, first the initial dynamic mobility of the pristine $\mathrm{TiO}_{2}$ is much higher, and the saturation concentration of the polymer is reached only at about $15 \mathrm{wt} \%$. Further addition of the polymer does not affect the dynamic mobility.

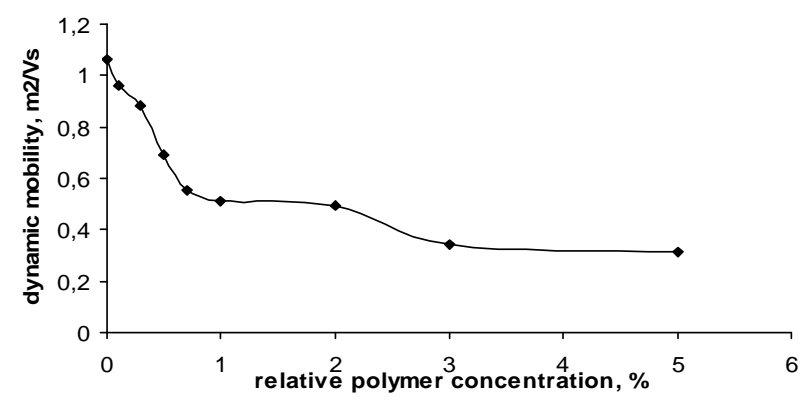

Fig. 1. Dependence of the dynamic mobility on the relative concentration of EHEC for $1 \mathrm{wt} \% \mathrm{TiO}_{2}$ aqueous dispersion without ultrasonic treatment

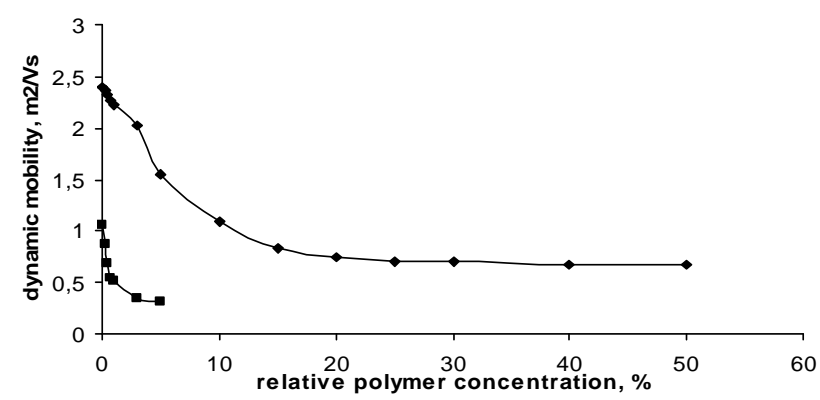

Fig. 2. Dependence of the dynamic mobility on the relative concentration of EHEC for $1 \mathrm{wt} \% \mathrm{TiO}_{2}$ aqueous dispersion with $(\mathrm{u})$ and without ultrasonic treatment (n, cf. Fig. 1)

However, e.g. for the system with $50 \mathrm{wt} \%$ polymer relative to $1 \mathrm{wt} \%$ pigment dispersion, it was observed that the dynamic mobility was further decreased to $0.35 \mathrm{~m}^{2} / \mathrm{Vs}$ after 1 day. This means that even though the ultrasonic power was shut off, the polymer deposition still occurred, indicating that the polymolecular adsorption in case of treated samples proceeds over a longer period of time. Obviously the ultrasonic action not only increases the pigment surface by creating a more fine dispersion but also activates the pigment surface leading to an ultimately higher polymer adsorption in comparison to the nontreated samples. Similar results were obtained for $\mathrm{Fe}_{2} \mathrm{O}_{3}$ aqueous dispersions as revealed from Figs. 3 and 4.

Comparing the values of saturation concentration without and after ultrasonic treatment, one can infer that the amount of polymer adsorbed on the particle surface 
significantly increases when ultrasonification is applied. In this context it has to be considered that the ultrasonic treatment leads to a finer dispersion by decreasing the particle size, and, consequently leading to an increase of the surface area prone to the polymer deposition. Thus both the increase of the dispersed particles on the total surface area and a possible ultrasonically induced activation of the particle surface must be considered as being responsible for the observed effects.

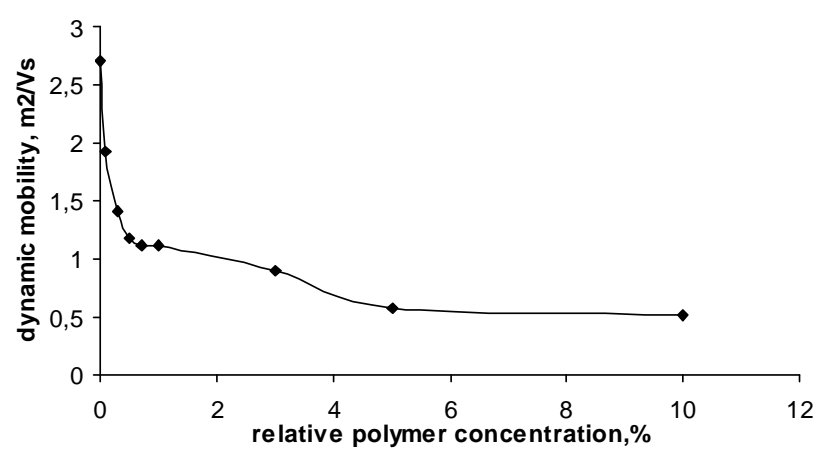

Fig. 3. Dependence of the dynamic mobility on the relative concentration of EHEC for $1 \mathrm{wt} \% \mathrm{Fe}_{2} \mathrm{O}_{3}$ aqueous dispersion without ultrasonic treatment

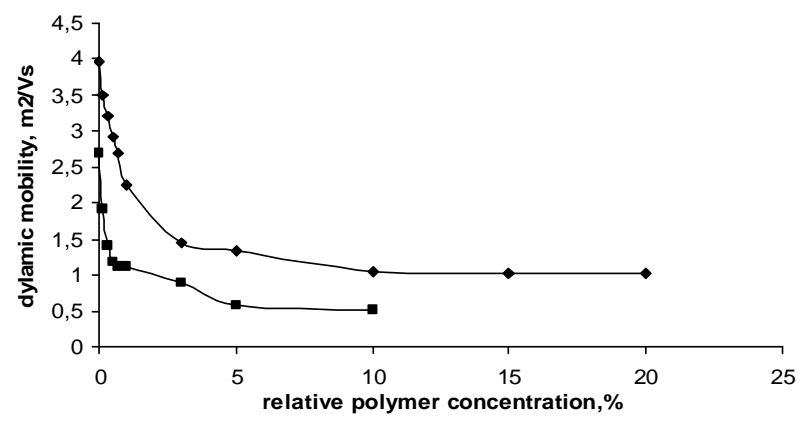

Fig. 4. Dependence of dynamic mobility on relative concentration of EHEC for $1 \mathrm{wt} \% \mathrm{Fe}_{2} \mathrm{O}_{3}$ aqueous dispersion with ( $\mathrm{u}$ ) and without ultrasonic treatment (n, cf. Fig. 1)

To get some quantitative information about the particulars of the polymer adsorption and to explain the increased amount of the polymer adsorbed when ultrasonic treatment was applied, the surface area of the uncoated pigment and of the polymer coated pigment were calculated; these data were compared with information obtained from TEM pictures of the particulate system and further related to data derived from ESA measurements.

First, the total surface area of the particles as related to the particle radius was calculated:

The total surface area $S_{\text {tot }}$ of all particles in the dispersion can be expressed by:

$$
S_{\text {tot }}=S_{\text {part }} \cdot n_{\text {part }}
$$

where $S_{\text {part }}$ is the surface area of a single particle, and $n_{\text {part }}$ is the number of particles.

Assuming the particles to be spherical, the surface area of one particle can be calculated from the particle radius $r_{\text {part }}$ :

$$
S_{\text {part }}=4 \pi r_{\text {part }}^{2}
$$

The number of particles in the dispersion as related to the particle radius is given by:

$$
n_{\text {part }}=\frac{m_{\text {total }}}{m_{\text {part }}}=\frac{m_{\text {total }}}{V_{\text {part }} \cdot \rho_{T_{i i O_{2}}}}=\frac{3 m_{\text {total }}}{4 \pi \cdot r_{\text {part }}^{3} \cdot \rho_{T_{i O_{2}}}}
$$

where $m_{\text {total }}$ is the total mass of the pigment in the dispersion, $m_{\text {part }}$ is the mass of a single particle, $V_{\text {part }}$ is the single particle volume, and $\rho_{\mathrm{TiO}_{2}}$ is the density of titanium dioxide.

Thus, the formula for the total surface area of all particles in the dispersion is expressed by:

$$
S_{\text {tot }}=\frac{4 \pi \rho_{\text {part }}^{2} \cdot 3 m_{\text {total }}}{4 \pi \cdot r_{\text {part }}^{3} \cdot \rho_{\mathrm{TiO}_{2}}}=\frac{3 m_{\text {total }}}{r_{\text {part }} \cdot \rho_{\mathrm{TiO}_{2}}}
$$

The ratio of the total particle surface area of the ultrasonically treated (index 2) and non-treated (index 1) dispersions is given by:

$$
\frac{S_{\text {tot } 2}}{S_{\text {tot } 1}}=\frac{3 m_{\text {total }} \cdot r_{\text {part } 1} \cdot \rho_{T i O_{2}}}{3 m_{\text {total }} \cdot r_{\text {part } 2} \cdot \rho_{T i O_{2}}}=\frac{r_{\text {part } 1}}{r_{\text {part } 2}}=\frac{d_{\text {part } 1}}{d_{\text {part } 2}}
$$

Thus, the ratio between the values of the particle surface area $\frac{S_{t o t 2}}{S_{t o t 1}}$ can be expressed as the reverse ratio of the average particle diameters, i.e. $\left(\frac{d_{\text {part } 2}}{d_{\text {part } 1}}\right)^{-1}$.

Using this equation and by inserting the values of the particle size in the saturation concentration of ultrasonically treated and non-treated samples of $\mathrm{TiO}_{2}$ and $\mathrm{Fe}_{2} \mathrm{O}_{3}$ dispersion aqueous in EHEC-solution, it is possible to calculate the increasing of particles surface area during the ultrasonic treatment. These data are given in Table 1.

From Table 1 it is seen that for both systems the particle surface area is increased by a factor of 3.4-4.7 upon ultrasonic treatment of the dispersion. However, the saturation concentrations for these systems are increased by a factor of 7-15. This indicates that the amount of polymer adsorbed per unit of the particle surface after ultrasonic treatment is higher in comparison with nontreated samples; this also means an increased thickness of the adsorption layer in the case of ultrasonically treated dispersions. 
Effect of ultrasonic treatment on particle diameter $\left(d_{\text {part }}\right)$ and increase of particle surface area $\left(S_{t o t}\right)$ in comparison to the saturation concentration $(S C)$ of polymer adsorption; indices 1, 2: non-treated and ultrasonically treated sample

\begin{tabular}{|c|c|c|c|c|}
\hline \multirow[b]{2}{*}{ System } & \multicolumn{2}{|c|}{ Averaged particle diameter, $\mu \mathrm{m}$} & \multirow{2}{*}{$\begin{array}{l}\text { Ratio between } \\
\text { particle surface area } \\
\text { with and without } \\
\text { ultrasonic treatment } \\
\quad S_{\text {tot } 2} / S_{\text {tot } 1}\end{array}$} & \multirow{2}{*}{$\begin{array}{c}\text { Ratio between } \\
\text { saturation } \\
\text { concentration with and } \\
\text { without ultrasonic } \\
\text { treatment } \\
S C_{2} / S C_{1}\end{array}$} \\
\hline & $\begin{array}{l}\text { Without } \\
\text { ultrasonic } \\
\text { treatment }\end{array}$ & $\begin{array}{c}\text { After } \\
\text { ultrasonic } \\
\text { treatment }\end{array}$ & & \\
\hline $\begin{array}{c}\mathrm{TiO}_{2}+\mathrm{EHEC} \\
\mathrm{Fe}_{2} \mathrm{O}_{3}+\mathrm{EHEC}\end{array}$ & $\begin{array}{c}0.85 \\
1.4\end{array}$ & $\begin{array}{c}0.25 \\
0.3\end{array}$ & $\begin{array}{l}3.4 \\
4.7\end{array}$ & $\begin{array}{c}15 \\
7\end{array}$ \\
\hline
\end{tabular}

Table 2

Ratios between saturation concentration $(S C)$ and corresponding change of dynamic mobility $\Delta \mu$ for pigment dispersion without (index 1) and with (index 2) ultrasonic treatment

\begin{tabular}{|c|c|c|c|c|}
\hline System & $\begin{array}{c}\text { Ratio between } \\
\text { saturation } \\
\text { concentration after } \\
\text { and without } \\
\text { ultrasonic treatment } \\
S C_{2} / S C_{1} \\
\end{array}$ & $\begin{array}{c}\text { Difference between } \\
\text { dynamic mobility of } \\
\text { pure pigment and that } \\
\text { at the saturation } \\
\text { concentration without } \\
\text { ultrasonic treatment } \\
\Delta \mu_{1} \\
\end{array}$ & $\begin{array}{l}\text { Difference between } \\
\text { dynamic mobility of } \\
\text { pure pigment and that } \\
\text { at the saturation } \\
\text { concentration after } \\
\text { ultrasonic treatment } \\
\Delta \mu_{2} \\
\end{array}$ & $\Delta \mu_{2} / \Delta \mu_{1}$ \\
\hline $\begin{array}{c}\mathrm{TiO}_{2}+\mathrm{EHEC} \\
\mathrm{Fe}_{2} \mathrm{O}_{3}+\mathrm{EHEC}\end{array}$ & $\begin{array}{c}15 \\
7\end{array}$ & $\begin{array}{l}0.5 \\
1.7\end{array}$ & $\begin{array}{l}1.7 \\
2.5\end{array}$ & $\begin{array}{l}3.4 \\
1.47\end{array}$ \\
\hline
\end{tabular}

Table 3
Thicknesses (d; cf. Eq. (6)) of the EHEC polymer adsorption layer on the $\mathrm{TiO}_{2}$ and $\mathrm{Fe}_{2} \mathrm{O}_{3}$ for treated and non-treated dispersions as calculated on the basis of the saturation concentration obtained from the ESA measurements

\begin{tabular}{|c|c|c|c|}
\hline System & $\begin{array}{c}\text { Thickness of } \\
\text { adsorption layer } \\
\text { without ultrasonic } \\
\text { treatment, nm }\end{array}$ & $\begin{array}{c}\text { Thickness of } \\
\text { adsorption layer } \\
\text { after ultrasonic } \\
\text { treatment, } \mathrm{nm}\end{array}$ & $\begin{array}{c}\text { Ratio between } \\
\text { thicknesses of treated } \\
\text { and non-treated } \\
\text { samples }\end{array}$ \\
\hline $\mathrm{TiO}_{2}+\mathrm{EHEC}$ & 5 & 17 & 3.4 \\
$\mathrm{Fe}_{2} \mathrm{O}_{3}+\mathrm{EHEC}$ & 11 & 16 & 1.5 \\
\hline
\end{tabular}

The difference of the dynamic mobility $\Delta \mu$ between the pure and EHEC coated pigments (at the saturation concentration) is higher for the ultrasonically treated $\left(\Delta \mu_{2}\right)$ than the non-treated $\left(\Delta \mu_{1}\right)$ samples (see Table 2). The proportionality between the $\Delta \mu_{2} / \Delta \mu_{1}$ ratio (last column Table 2) of the two pigment systems is similar as the ratio $S C_{2} / S C_{1}$ of the saturation concentration (second column Table 2).

Thus the correlation of the ESA measurement data with regard to the established saturation concentration and the change in the dynamic mobility give a conclusive picture of the effects of ultrasonic treatment on the pigment/EHEC interaction which is in accordance with the calculations of the particle surface/particle diameter relation (Eq. 5).

As it was proven by refraction index measurements of the supernatant liquid of sedimented pigment dispersions, up to the saturation concentration of the polymer, all polymers added to the system are adsorbed on the particle surface; only when this concentration was exceeded, a change in the index of refraction due to the dissolved polymer was observed. Thus, since the amount of polymer adsorbed and the surface area of the particles are known, the thickness of adsorption layers is given by Eq. (6) where the total area of the particles $S_{t o t}$ is calculated by Eq. (4): 


$$
d=\frac{V_{t o t}}{S_{t o t}}
$$

The volume of the adsorption layer $V_{\text {tot }}$ is given by the ratio of the mass of the polymer adsorbed $m_{\text {tot pol }}$ to the density $\rho_{p o l}$ of the polymer (Eq. 7):

$$
V_{t o t}=\frac{m_{t o t ~ p o l}}{\rho_{p o l}}
$$

The relationship of Eqs. (6) and (7) allows to calculate the thickness of the adsorption layers on the pigment surface for both ultrasonically treated and untreated pigment dispersions. The data are presented in Table 3. One can see that the thickness of the adsorption layer increases by the ultrasonic treatment for both systems tested. This confirms that during the ultrasonic treatment an activation of the pigment surface occurs.

Aqueous dispersions of $\mathrm{TiO}_{2}$ and $\mathrm{Fe}_{2} \mathrm{O}_{3}$ stabilized by EHEC were also investigated by transmission electron microscopy (TEM) in order to visualize the change of the dispersed system upon ultrasonic treatment, and also to confirm the above conclusions about the thicknesses of the EHEC polymer adsorption layer.

From the TEM picture (Fig. 5) it is seen that the dispersion of $\mathrm{TiO}_{2}$ without the added polymer stabilizer and without ultrasonic treatment consists of aggregates of about 5-10 particles; the size of such aggregates of the non-treated system is about $1 \mu \mathrm{m}$ and is in agreement with Nanosizer and ESA data. However, the dispersion of $\mathrm{TiO}_{2}$, again without EHEC, after ultrasonic treatment consists of extended aggregates (Fig. 6) of sizes up to $4-5 \mu \mathrm{m}$; this size increase is due to the activation of the pigment particle surface by the ultrasonic power. As a result of this coagulation, fast sedimentation of the dispersion occurs. From Figs. 5 and 6 it is also evident that the primary particles are spherical in shape; this confirms the assumption made above in the calculation of the particle surface area.

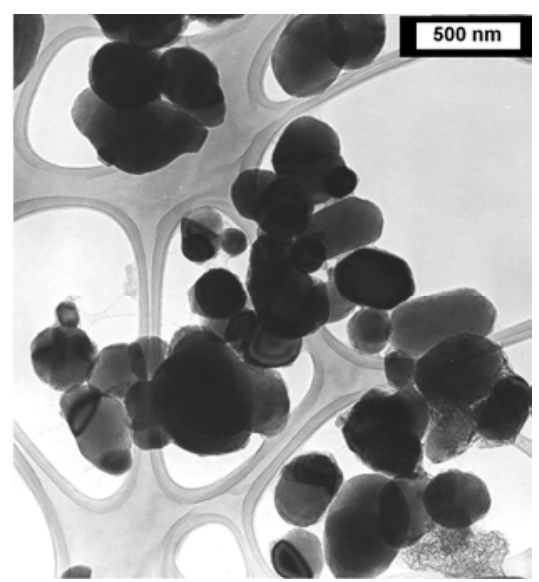

Fig. 5. TEM picture of $\mathrm{TiO}_{2}$ aqueous dispersion without polymer stabilizer and without mechanical (ultrasonic) treatment

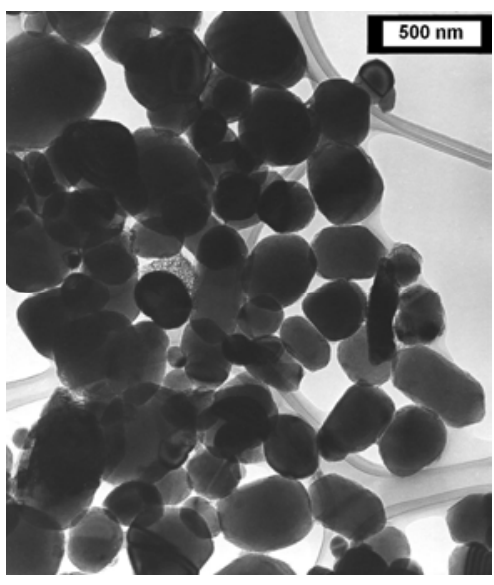

Fig. 6. TEM picture of $\mathrm{TiO}_{2}$ aqueous dispersion without polymer stabilizer after ultrasonic

When the dispersion of $\mathrm{TiO}_{2}$ or $\mathrm{Fe}_{2} \mathrm{O}_{3}$ pigments is carried out with added EHEC, the polymer acts as a stabilizer and primary particle dispersions are obtained. As it is seen from the comparison of the TEM pictures of $\mathrm{TiO}_{2}$ or $\mathrm{Fe}_{2} \mathrm{O}_{3}$ aqueous dispersions stabilized by EHEC (polymer concentration chosen corresponding to the saturation concentration as obtained from ESA measurements, Figs. 1-4) which were obtained without (Figs. 7 and 9) and with ultrasonic treatment (Figs. 8 and 10), the ultrasonification leads to an increased thickness of the EHEC coating layer around the primary particles.

These findings are in agreement with the much higher polymer saturation concentration required in the ultrasonically treated dispersions (see Figs. 2 and 4) as compared to the non-treated systems (see Figs. 1 and 3) which has already been discussed above (Table 1 and Table 2). The thickness of the adsorption layers strongly increases from 4-6 $\mu \mathrm{m}$ if dispersions are not treated ultrasonically, and to about $15-20 \mu \mathrm{m}$ when the ultrasonic treatment is applied. This is in rough agreement with the values calculated above from ESA data (see Table 3).

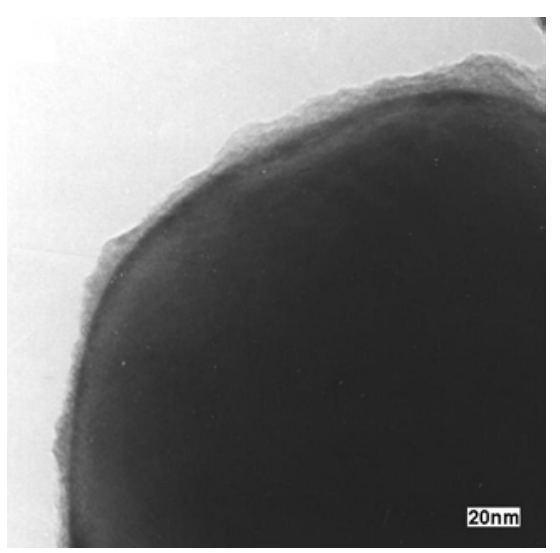

Fig. 7. TEM picture of $\mathrm{TiO}_{2}$ primary particle aqueous dispersion stabilized by EHEC ( $1 \mathrm{wt} \%$ relative pigment) without mechanical (ultrasonic) treatment 


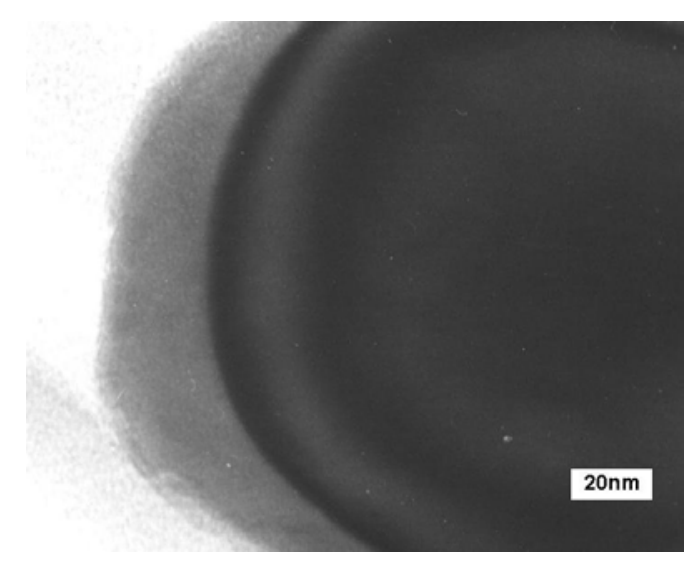

Fig. 8. TEM picture of $\mathrm{TiO}_{2}$ primary particle aqueous dispersion stabilized by EHEC ( $15 \mathrm{wt} \%$ relative pigment) after ultrasonic treatment

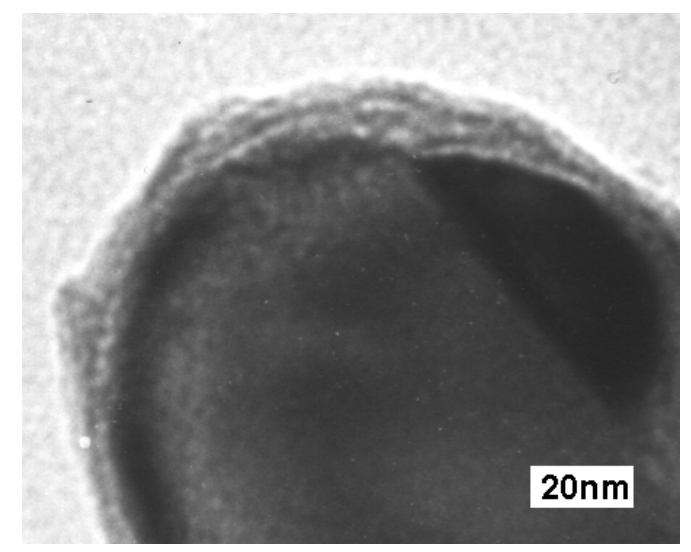

Fig. 9. TEM picture of $\mathrm{Fe}_{2} \mathrm{O}_{3}$ primary particle aqueous dispersion stabilized by EHEC ( $1 \mathrm{wt} .-\%$ relative pigment) without mechanical (ultrasonic) treatment

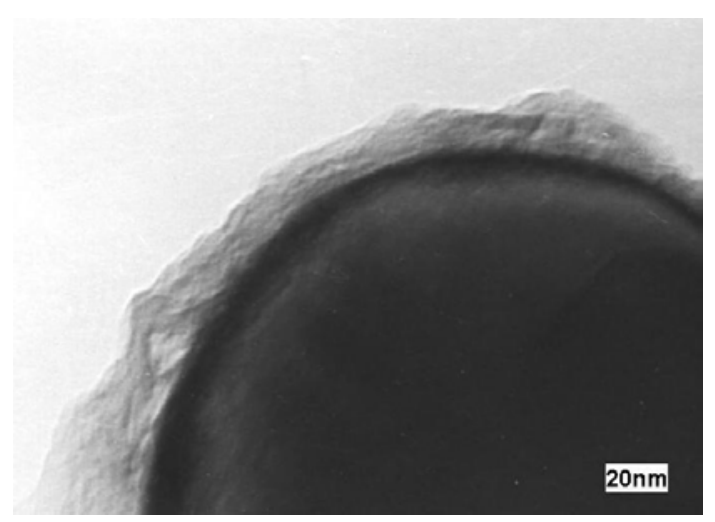

Fig. 10. Picture of $\mathrm{Fe}_{2} \mathrm{O}_{3}$ aqueous dispersion stabilized by EHEC ( $7 \mathrm{wt} \%$ relative to pigment) after ultrasonic treatment

Thus, the TEM investigations allow to conclude that mechanical, i.e. ultrasonic treatment has a pronounced effect on the pigment-polymer interaction in the dispersed system: the amount of the polymer adsorbed and the thickness of the adsorption layer are significantly increased due to the activation of the particle surface.

In order to further elucidate the origin of this polymer adsorption layer growth, ESA measurements under variation of the frequency of the applied alternating electrical field have been carried out. These data can be used to get quantitative information about the structure of the adsorption layers according to the polymer gel layer theory (cf. [15]). In this theory it is assumed that the polymer adsorption layer consists of an inner layer of polymers adsorbed on the particle surface and an outer layer formed by the interpolymer interactions; the inner layer has a higher density and its formation is a direct result of pigment-polymer interactions.

The procedure given in literature [16] for the calculation of the thicknesses of the inner $(\Delta)$ and outer $(\delta)$ polymer adsorption layers after the polymer gel layer theory was applied for non-treated and ultrasonically treated dispersions of $\mathrm{TiO}_{2}$ and $\mathrm{Fe}_{2} \mathrm{O}_{3}$, stabilized by EHEC. The formula for calculating the relative dynamic mobility $\mu / \mu_{0}$ (ratio of the dynamic mobility $\mu$ measured for the polymer containing pigment dispersion to the dynamic mobility $\mu_{0}$ of the polymer free dispersion) is given in Eq. (8):

$$
\begin{gathered}
\frac{\mu}{\mu_{0}}=I^{-\kappa \Delta}\left\{-\frac{i \omega \alpha / \gamma-k^{2}}{k^{2}-\kappa^{2}} \cdot\left[I^{-\kappa \delta}\left(1+\frac{\kappa}{k} \tanh k \delta\right)-\right.\right. \\
\left.\left\{-\frac{\kappa^{2}}{k^{2} \cosh k \delta}\right]-\frac{i \omega \alpha}{\gamma k^{2}}\right\}
\end{gathered}
$$

Here the quantity $k$ is given by:

$$
k^{2}=\frac{\alpha}{\eta}\left(1+\frac{i \omega \eta}{\gamma}\right)
$$

and the quantity $\gamma$ by:

$$
\gamma=\omega_{0} \eta
$$

where $\Delta-$ thickness of the inner adsorption layer, $\delta$ - thickness of the outer adsorption layer, $\omega-$ frequency, $\eta$ - dynamic viscosity, $\kappa$ - Debye-Huckel parameter, $\alpha$-drag coefficient, $\omega_{0}$ - relaxation frequency.

In our case one has to take into account the differences in the particle size and particle inertia factor in the dispersion which was proven not to be the same for both ultrasonically treated and non-treated samples without and with the addition of EHEC polymer. For ultrasonically non-treated samples, the difference is due to the disjoining forces (Deryagin's effect), for treated samples this deflocculation results from both the ultrasonic treatment as well as the stronger polymer adsorption which decreases the particle interaction strength (Rebinder's effect). The inertia factor $G(r)$ can be calculated by the formula (11):

$$
G(r)=\frac{1+(1+i) \sqrt{r / 2}}{1+(1+i) \sqrt{r / 2}+i(r / 9)\left(3+2\left(\Delta \rho / \rho_{m}\right)\right)}
$$


where $r$ is the particle radius, $\rho_{m}$ is the density of the solvent, $\Delta \rho$ is the difference between densities of the particles and the solvent.

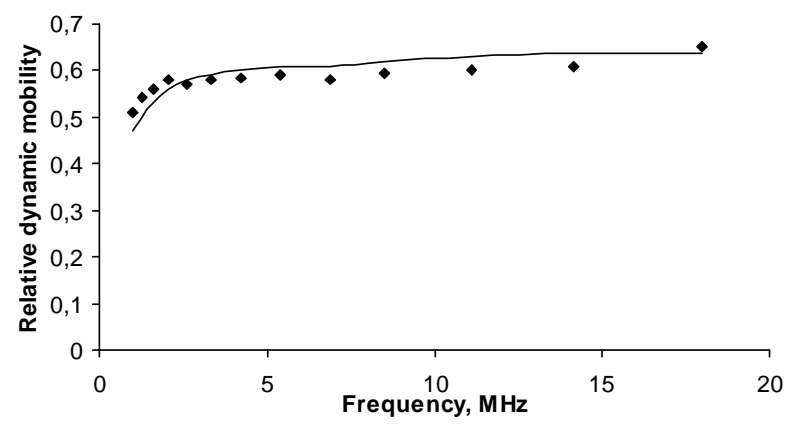

Fig. 11. Dependence of the relative dynamic mobility on frequency for aqueous $\mathrm{TiO}_{2}$ dispersions stabilized by EHEC (1 wt \% relative to pigment) without ultrasonic treatment: experimental data $(\mathrm{U})$ and calculated theoretical curve (solid line)

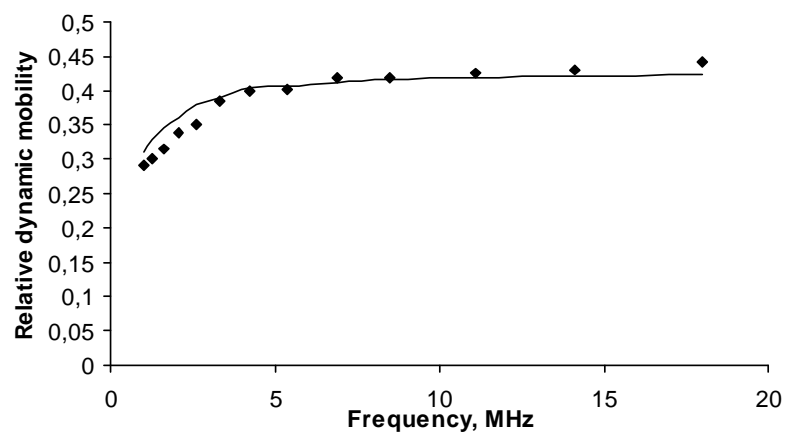

Fig. 12. Dependence of the relative dynamic mobility on frequency for aqueous $\mathrm{TiO}_{2}$ dispersions stabilized by EHEC (15 wt \% relative to pigment) without ultrasonic treatment: experimental data $(\mathrm{u})$ and calculated theoretical curve (solid line)

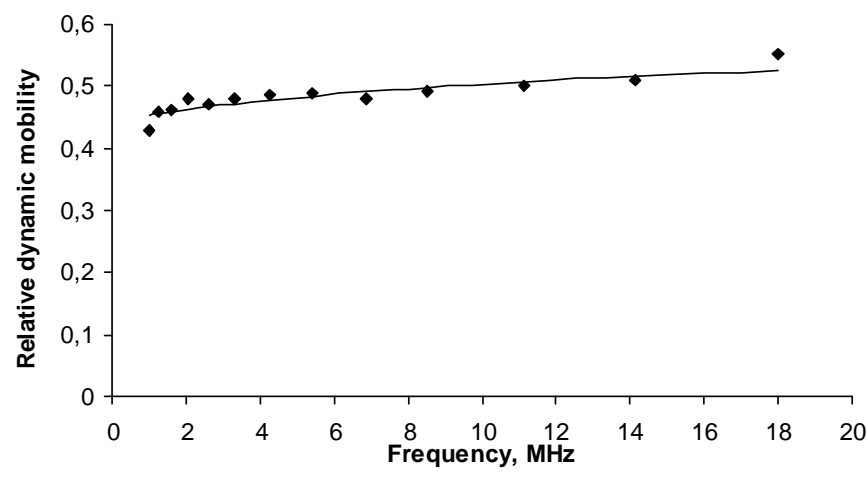

Fig. 13. Dependence of the relative dynamic mobility on frequency for aqueous $\mathrm{Fe}_{2} \mathrm{O}_{3}$ dispersions stabilized by EHEC (1 wt \% relative to pigment) without ultrasonic treatment: experimental data $(\mathrm{u})$ and calculated theoretical curve (solid line)

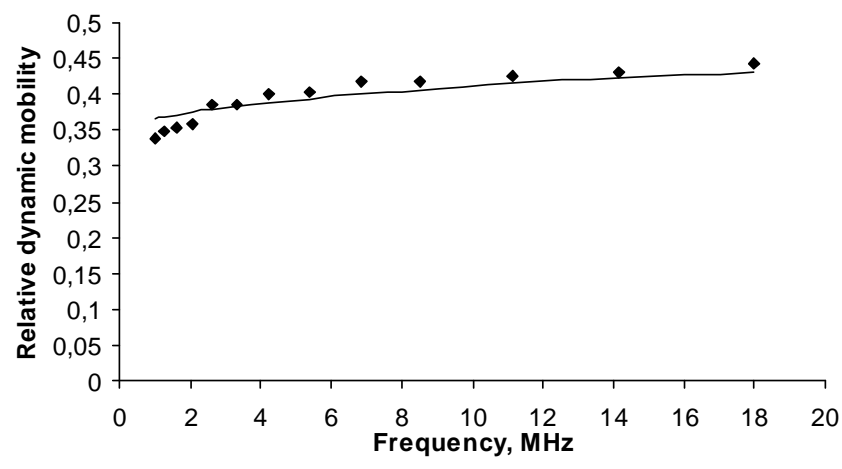

Fig. 14. Dependence of the relative dynamic mobility on frequency for aqueous $\mathrm{Fe}_{2} \mathrm{O}_{3}$ dispersions stabilized by EHEC ( $7 \mathrm{wt} \%$ relative to pigment) without ultrasonic treatment: experimental data $(\mathrm{u})$ and calculated theoretical curve (solid line)

Table 4

Thickness of inner $(\Delta)$ and outer $(\delta)$ EHEC polymer adsorption layer on $\mathrm{TiO}_{2}$ and $\mathrm{Fe}_{2} \mathrm{O}_{3}$ pigment for dispersions without and with ultrasonic treatment as calculated from Eq. (8) by using experimental ESA data (see text)

\begin{tabular}{|c|c|c|c|c|}
\hline \multirow{2}{*}{ System } & \multicolumn{2}{|c|}{$\begin{array}{c}\text { Thickness }(\Delta) \text { of the inner adsorption } \\
\text { layer, } \mathrm{nm}\end{array}$} & \multicolumn{2}{c|}{$\begin{array}{c}\text { Thickness }(\delta) \text { of the outer adsorption } \\
\text { layer, nm }\end{array}$} \\
\cline { 2 - 5 } & $\begin{array}{c}\text { without ultrasonic } \\
\text { treatment }\end{array}$ & $\begin{array}{c}\text { with ultrasonic } \\
\text { treatment }\end{array}$ & $\begin{array}{c}\text { without ultrasonic } \\
\text { treatment }\end{array}$ & $\begin{array}{c}\text { with ultrasonic } \\
\text { treatment }\end{array}$ \\
\hline $\mathrm{TiO}_{2}+\mathrm{EHEC}$ & 1.2 & 8.7 & 4.7 & 6.5 \\
$\mathrm{Fe}_{2} \mathrm{O}_{3}+\mathrm{EHEC}$ & 2.4 & 3.8 & 7.3 & 7.7 \\
\hline
\end{tabular}

First, the relative dynamic mobility, i.e. the ratios between experimentally obtained values of the dynamic mobility of pigment particles covered by the polymer and those of non-covered particles were established for the whole frequency range (data points in Figs. 11-14). Then, using the Eq. (8), the thicknesses of inner $(\Delta)$ and outer $(\delta)$ adsorption layers were calculated. These data are compiled in Table 4. Inserting averaged values into the formula (8) one gets the theoretical dependency of the relative dynamic mobility (ratio between dynamic 
mobilities of polymer-coated and pure particles) from the frequency of the applied electrical field (lines in Figs. 1114). The comparison of the experimental and theoretical data allows to check the correctness of the calculations; it is evident that for all cases the theoretical curves were in good agreement with the experimental data.

The total thickness of the EHEC polymer adsorption layer as given by the sum of the inner and outer adsorption layer as calculated by applying the gel layer theory (see data Table 4) is in fair agreement with the values based on the polymer saturation concentration established by the concentration dependency of the ESA signals (see Table 3). The comparison of the values of thicknesses of the inner and outer adsorption layers of the dispersion without and with ultrasonic treatment reveals that for both systems investigated the ultrasonic treatment predominantly effects the thickness of the inner layer which is especially prominent for the $\mathrm{TiO}_{2}$ pigment. This reflects the activation of the pigment surface by the ultrasonic power leading to an increased adsorption of the polymer; on the other hand, the outer layer which results from interpolymer interactions is less effected and maintains relatively unchanged in thickness.

\section{Conclusions}

ESA and TEM measurements have shown that the improved colloidal stability of ultrasonically treated dispersed pigment/polymer stabilizer systems as known from sedimentation studies is due to special ultrasonic treatment related to pigment-polymer interactions. For aqueous $\mathrm{TiO}_{2}$ and $\mathrm{Fe}_{2} \mathrm{O}_{3}$ dispersions stabilized by EHEC, the saturation concentrations of polymer surfactants, i.e. the maximum amount of the adsorbed polymer were established, and the increasing of the thickness of the adsorption layers upon ultrasonic treatment was proven by ESA measurements and confirmed by TEM investigations of the dispersed systems.

By means of the ESA technique insights into the ultrasonically induced change of the thickness and structure of the polymer adsorption layers were obtained by applying the gel layer theory: In particular, the data allow to conclude that ultrasonic treatment of aqueous inorganic pigment dispersions is a powerful method for the pigment surface modification leading first to an activation of the pigment surface; as a consequence, improvement of the pigment-polymer interaction is achieved which results in the creation of polymer adsorption layers of high thickness.

Thus ultrasonic treatment enables to obtain stable and high-dispersed pigment suspensions with modified pigment surface; this method opens new perspectives for modifying the pigment surface more efficiently.

\section{References}

[1] Holmberg K., Jönsson B., Kronberg B. and Lindman B.: Surfactants and Polymers in Aqueous Solution", $2^{\text {nd }}$ edn. J. Wiley \& Sons, Chichester, UK 2003.

[2] Netz R. and Andelman D.: Physics Reports, 2003, 380, 1.

[3] Somasundaran P. and Krishnakumar S.: Colloids and Surfaces A, 1997, 123, 491.

[4] Theo G. and de Ven V.: Adv. Colloid Interface Sci., 1994, 48, 121.

[5] Somasundaran P. and Yu X.: Adv. Colloid Interface Sci., 1994, $\mathbf{5 3}, 33$.

[6] Zubov V., Kuzkina I., Ivankova I and Schmitz O.: Eur. Coating J., 1998, 12, 954 .

[7] Zubov V., Kuzkina I., Ivankova I. and Schmitz O.: Eur. Coating J., 1998, 11, 856.

[8] Antonietti M. and Weissenberger M.: Macromol. Rapid. Com., 1997, 18, 295.

[9] Zubov V., Serebryakova N., Arutyunov I. et al.: Colloid J., 2004, 66, 302 .

[10] Bulychev N., Arutunov I., Zubov V. et al.: Macromol. Chem. \& Phys., 2004, 205, 2457.

[11] Bulychev N., Fomin V., Arutunov I. et al.: Materialovedenie, 2005, 4, 20.

[12] Eisenbach C., Schaller Ch., Schauer T. and Dirnberger K.: ACS Symposium Series 881 "Particle Sizing and Characterization",

American Chemical Society, 2004, 215.

[13] Schaller C., Schoger A., Dirnberger K. et al.: Macromol. Symp., 2002, 179, 173.

[14] Schaller C., Schauer T., Dirnberger K. and Eisenbach C.: Eur. Phys. J., 2001, E 6, 365.

[15] O’Brien R.: J. Fluid Mech., 1988, 190, 71.

[16] Carasso M., RowlandsW. and O'Brien R.: J. Colloid Interface Sci., 1997, 193, 200.

\section{НАНОСТРУКТУРНІ ХАРАКТЕРИСТИКИ ПОЛІМЕРНИХ АДСОРБЦЙНИХ ШАРІВ, УТВОРЕНИХ НА ПОВЕРХНІ ОКСИДІВ МЕТАЛІВ У ВОДНИХ ДИСПЕРСНИХ СИСТЕМАХ ПІД ДІЕЮ УЛЬТРАЗВУКУ}

\begin{abstract}
Анотація. За допомогою електрокінетичної звуковоі амплітуди (ЕЗА) досліджено прочес модифікаиії поверхні пігментів діоксиду титану та оксиду заліза у водних дисперсних системах при введенні етилгідроксиетилцелюлози (ЕГЕЦ) у відсутності та в присутності механічного оброблення дисперсних систем ультразвуком. Інтерпретацією даних ЕЗА показано, щчо ультразвукове оброблення викликає суттєве збільшення товщини шару ЕГЕЦ на поверхні пігментів, щзо пояснюється ультразвуковою активацією поверхні. Дані про товщииу шарів, отримані методом ЕЗА, підтверджені дослідженнями з використанням просвічуючої електронної мікроскопії. Ультразвукове оброблення призводить до значних змін характеристик адсорбиійних шарів іє перспективним методом для модифікування поверхні пігментів та підвищення стабільності дисперсних систем.
\end{abstract}

Ключові слова: водні дисперсні системи, полімери, метод електрокінетичної звукової амплітуди, полімерні адсорбиійні шари, ультразвукове оброблення. 